\title{
'I once knew a team where all the workers called the manager "mother" '.....Some reflections on supervision within an integrated leadership and management programme
}

\begin{abstract}
In 2010, an integrated Leadership, Management and Safeguarding training programme for adult and children's services managers was created by a group of local authorities and a local university. Following Lord Laming (Department of Health, 2003 and Laming, 2009), the emerging reports of Munro (2010) and the Social Work Task Force (Department for Children, Schools and Families, 2009) called for increased emphasis on supervision as a key mechanism for safeguarding children, and by implication, adults. Therefore on this course two different means for candidates to address issues of supervision and explore their practice were included: a discussion board, and a critical friend exercise using video. A feature of the programme was the learning and understanding which developed from adults and children's sectors learning together. The work on supervision provided a shared space in which all could participate. Feedback indicates that the two methods were both valued in different ways for the opportunity they provided for exploring supervision and enhancing reflective practice. This article is a reflection by one of the course tutors on the methods used and the value of both adult and children's managers participating together.
\end{abstract}

\section{Introduction}

\section{Background}

At the end of 2010, Skills for Care provided funding which enabled several local authorities to work with a neighbouring university to create an integrated Leadership, Management and Safeguarding training programme for adult and children's services managers (Skills for Care, 2010). The course was co-created within an established university and local authority partnership, to address the need identified by local agencies for training which addressed some of the safeguarding issues faced by social work managers. Initially the course had been designed for children's services managers in response the agencies' perceptions

1 'I once knew a team where all the workers called the manager "mother" '.....Some reflections on supervision within an integrated leadership and management programme

Social Work and Social Services Review article Revised May $28^{\text {th }} 2013$ 
of gaps in their managers' knowledge and skills in the wake of Laming (2009) and the emerging recommendations of Munro (2010) and the Social Work Task Force (Department for Children Schools and Families, 2009) . Increased emphasis on supervision was regarded as a key mechanism for safeguarding children, and by implication, adults. Following the Skills for Care initiative, the programme was extended and amended to incorporate adult services managers.

In our initial brief, we had stated our intention to meet the needs of both managers who are social workers but inexperienced, and managers who are experienced but may not be social work trained though having responsibility for supervising social work employees. In fact participants also included more experienced social work managers attracted, we believe, by the emphasis on supervision, safeguarding and risk. Participants were from both adults and children's services, included occupational therapists, nurses and police as well as social workers, and were responsible for managing a range of interdisciplinary teams.

An evaluation of the programme as a whole has been undertaken and will be published separately. This article will focus on the e learning discussion board and critical friend video exercise and will reflect on the usefulness of this approach in enhancing reflective supervision, drawing on the analysis of the critical friend reports, feedback on the course and the content of the discussion board exercise.

\section{Philosophy and principles}

Adult safeguarding has gradually come into focus since "No Secrets" was published in 2000 (Department of Health, 2000) with inquiries into the deaths of Steven Hoskin (Flynn, 2007) and Fiona Pilkington in Leicestershire (Community Care, 2009) bringing the issue into prominence. In children's services safeguarding issues have been at the forefront of service provision since the Victoria Climbie inquiry (Laming, 2003) and "Every Child Matters" (2003). It has been acknowledged that the study of serious case reviews in adult services has lagged behind that in children's services (Manthorpe and Martineau, 2010), although the amount of deep learning which has taken place from children's serious case reviews is open to debate (Brandon et al, 2005; Fish et al 2008; Brandon et al 2010). Manthorpe and Martineau (2010) have noted the central role of social work managers (rather than other professions) in implementing adult protection systems.

The idea for the programme grew out of a long period of the university and local agencies working successfully together in post qualifying social work education, and the development within that context of a safeguarding module for first line managers in children's services. This in itself had emerged from increasing awareness of the need to enhance the status of social work as a

2 'I once knew a team where all the workers called the manager "mother" '.....Some reflections on supervision within an integrated leadership and management programme

Social Work and Social Services Review article Revised May 28 2013 
profession (Laming, 2009; Munro, 2010); and that it was social work team managers (rather than other professionals) who were faced with particularly complex safeguarding issues. The scapegoating of social workers which intensified during the Baby Peter affair (Parton, 2011) reinforced the need for social work managers to be confident in their own decision making and their management of staff. While these reports related specifically to children, the steering group felt that similar issues faced adults services managers who faced the added challenges of few qualified staff and responsibility for widely diverse service areas within one team.

\section{Design of the course}

This was a short course, the teaching taking place over an 8 week period, with a further period for reflection and writing the assignment. The following table describes the structure of the course:

\begin{tabular}{|c|c|c|}
\hline Timeline & Content & Activity \\
\hline Week 1 & $\begin{array}{l}\text { Leadership and management theory } \\
\text { Analysis of Serious Case Reviews } \\
\text { (previously read) } \\
\text { The service user perspective (led by } \\
\text { service user group) }\end{array}$ & Lectures and group work \\
\hline Week 2 & $\begin{array}{l}\text { Leadership and management theory } \\
\text { continued } \\
\text { Supervision - theory and models }\end{array}$ & Lectures and group work \\
\hline Week 3 & Risk & Lectures and group work \\
\hline Week 4 & E learning exercise around supervision & $\begin{array}{l}\text { E learning; discussion } \\
\text { board }\end{array}$ \\
\hline $\begin{array}{l}\text { Weeks } 5 \\
\text { and } 6\end{array}$ & $\begin{array}{l}\text { Candidates undertake video exercise of } \\
\text { themselves giving supervision }\end{array}$ & Video \\
\hline Week 6 & Managing change and uncertainty & $\begin{array}{l}\text { Experiential activity; } \\
\text { group work }\end{array}$ \\
\hline Week 7 & $\begin{array}{l}\text { Further opportunity to complete } \\
\text { supervision video }\end{array}$ & Video \\
\hline
\end{tabular}

3 'I once knew a team where all the workers called the manager "mother" '.....Some reflections on supervision within an integrated leadership and management programme

Social Work and Social Services Review article Revised May $28^{\text {th }} 2013$ 


\begin{tabular}{|l|l|l|}
\hline Week 8 & $\begin{array}{l}\text { Critical friend activity, watching and } \\
\text { reflecting on videos }\end{array}$ & $\begin{array}{l}\text { Work in pairs with critical } \\
\text { friend }\end{array}$ \\
\hline Week 12 & $\begin{array}{l}\text { Submit assignment on risk and reflection } \\
\text { on supervision activity }\end{array}$ & \\
\hline
\end{tabular}

The candidates were required to view their supervision videos with a critical friend, write a report on their partner's video and then submit a 1000 word reflection on the process.

The second cohort being discussed here ran at the end of 2011, with 20 participants, 8 from adult services and 12 from children's. There was a mix of gender and ethnicity, though most participants were White.

The design of the work on supervision had roots in both pedagogy and social work. Educationally, adult learning theory learning informs us that candidates have different learning styles and therefore need varying opportunities for knowledge to be embedded (Biggs, 2003). From social work practice, the complexity and seriousness of the task being undertaken in supervision (Hawkins and Shohet, 2012) suggests that the maximum amount of time within a short programme should be devoted to the topic, whilst acknowledging that whole courses are held to cover each of the subjects outlined above. The steering group felt strongly that observation of supervision was a key aspect of learning and development, the only issue which arose was how the observation was to be carried out. This will be discussed further below. The discussion board activity was developed partly by external drivers: the request by agency partners for a "non- attendance" day, to help candidates with time management when combining work and study; and the ongoing push within the university for blended learning approaches and more use of e learning.

Before participating in the online activity, as part of the course the candidates had a day's workshop on supervision, comprising group work and teaching, which included the CLEAR approach ${ }^{1}$ and the 7 - eyed model $^{2}$ (Hawkins and Smith, 2006, Hawkins and Shohet, 1989 and 2012). The workshop, online discussion and work with a critical friend were intended to be a coherent whole.

1 The CLEAR model of supervision follows a Contract, Listen, Explore, Action, and Review structure (Hawkins and Smith, (2006).

2 The 7 -eyed model of supervision is a systemic and relational model first devised by Peter Hawkins which considers the interplay between the supervisor, supervisee and client (Hawkins and Shohet, 1989, 2012).

4 'I once knew a team where all the workers called the manager "mother" '.....Some reflections on supervision within an integrated leadership and management programme 
This article arose from the author's interest in the candidates' positive responses to the discussion board; the activity was not originally set up as a research project. The author analysed data from the content of the discussion board to ascertain themes. The critical friend reports and candidate feedback on the exercise were examined to elaborate on the observations, and to provide verification of the themes identified from the discussion board. Gray and Schubert (2012) suggest that evidence based practice is best developed through collaborative, engaged and participatory activity. This is what we were aiming to achieve in the programme as a whole, and in the supervision activity in particular. Consent for anonymised use of their work for this article was gained from the candidates retrospectively.

\section{The importance of supervision}

As already mentioned, the Laming report (2009), Munro $(2010,2011)$ and the Social Work Task Force has brought supervision to the fore as a key means of safeguarding children, and by implication, vulnerable adults. It has been suggested that supervision is now contested and can be seen as a means of surveillance and a function of managerialism (Jones, 2004; Beddoe, 2010). However, supervision has not always had this strong regulatory function. Harris (2003) describes the "pre-business era" of the 1970s and 80s as characterized by the separation of bureaucratic professional functions into different levels (central government, local government, middle management and front line management) which operated relatively autonomously. The area team enjoyed a high degree of decentralization and delegation (Harris, 2003), and "there was little scrutiny of team leaders' work with social workers and they could disregard specific departmental rules without negative consequences" (Satyamurti, 1981 in Harris, 2003, p 11): this permissive mode of supervision was well entrenched (Harris, 2003). "Teams often appeared to make decisions in a vacuum which was seldom filled by guidance from headquarters" (Parsloe, P., 1981, in Harris, 2003). The professional social workers autonomy on behalf of her clients was sacrosanct. This began to change as child deaths focused attention on the role of professionals and official agencies (Parton, 2011) amplified by intense and critical media interest. Social workers' power needed to be curbed through increased managerial controls (Dustin, 2007). Despite the emphasis on multi agency working in child protection during the New Labour period, Parton suggests that "Following the tragic death of Baby Peter, social workers became more concerned than ever with forensically investigating, assessing and managing cases of child abuse in a context that was even more high-profile and procedurally driven that ever before" (Parton, 2011, p 868). One way this scrutiny was to be accomplished was through supervision.

5 'I once knew a team where all the workers called the manager "mother" '.....Some reflections on supervision within an integrated leadership and management programme

Social Work and Social Services Review article Revised May $28^{\text {th }} 2013$ 
"Given the past decade has seen regulation invading almost every aspect of front line practice, it is perverse that so little has been done to quality assure an activity that arguably has the greatest influence on practice other than the practitioner herself ", (Morrison and Wonnacott, 2010). Morrison's concern was soon to be addressed. The Social Work Task Force recommended national requirements for the supervision of social workers (Recommendation 7) which are now embedded in government guidance (Department for Education, 2012), the first point of which states that employers should " have in place a social work accountability framework", increased accountability having been the rallying cry from successive child death inquiries (Lawler and Bilson, 2010).

According to the Government, the key elements of effective supervision encompass:

1. Quality of decision making and interventions

2. Line management and organisational accountability

3. Caseload and workload management

4. Identification of further personal learning, career and development opportunities

(Department for Education, 2012).

Most agencies now have a supervision policy, and prescribe a format in which supervision should take place, often requiring a pro forma to be completed; if the supervision discussion diverges from this set format, another form has to be completed explaining why (Dustin, 2007). Thus the role of the supervisor has become rather like a production line supervisor overseeing effort and standards of output (Lawler and Bilson, 2010). Kadushin's three functions of supervision as administrative, educational and supportive (Kadushin, 1992) have formed an accepted orthodoxy (Jones, 2004), however, the D f E's list above suggests that the "administrative" function has been expanded into three, whereas the other two, "educational" and "supportive" have been compressed into one. Dustin describes the paradox of increased managerial control alongside the McDonaldization (Ritzer, 1996) of service delivery in social work which emphasis the importance of consumer choice alongside increased "efficiency, predictability, calculability and control" (Dustin, 2007, p 26). It is within this paradox that social workers and their managers have to deal with issues of pain, distress and fear (Ferguson, 2010). Hawkins and Shohet (2012) define supervision thus:

"Supervision is a joint endeavour in which a practitioner with the help of a supervisor, attends to their clients, themselves as part of their client practitioner relationships and the wider systemic context, and by doing so improves the quality of their work, transforms their client relationships, continuously develop

6 'I once knew a team where all the workers called the manager "mother" '.....Some reflections on supervision within an integrated leadership and management programme 
themselves, their practice and the wider profession" (Hawkins and Shohet, 2012)

The fact that this does not appear to be the same activity as that outlined by the Government ( $D$ f $E, 2012$, above) indicates the complexity of the present day supervision task.

Hair suggests that "When social workers become supervisors, the knowledge that most informs their supervisory practice comes from their previous experiences being supervised" (Hair, 2012, p 5); some of our candidates had not had previous supervision training, so were relying on their own past experience to guide them.

\section{Methods}

\section{Peer observation}

It was decided early in the programme development that observation of supervision should be an element of the assessment, for reasons already outlined above (Laming, 2009; Social Work Task Force, 2009). Observation of practice has been embedded in social work training since at least 1991 when the Diploma in Social Work and Practice Teacher Award were introduced. However, since then there has been an ongoing debate about the observational model to be used, and the power differentials involved. Tanner, for example, in arguing for an Equality Model of observation, suggests that power permeates observation in all aspects. "These include the relationship between the observer and the observed, power relations within the observational system, and the power the observer has in creating the written material" (Tanner, 1998, p 49). For this programme the processes suggested were line manager observation or peer observation. Line manager observation raised issues of managerialism and control (Beddoe, 2010); peer observation however had considerable educational advantages, as well as confronting some of the power issues inherent in observation. It was decided that video would be used, rather than direct peer observation, alongside a critical friend model of reflection (Costa and Kallick, 1993). Bell and Mladenovich in their study of peer observation of teaching, referring to Lomas and Nicholls, suggest that to be fully effective, peer observation should be "non- judgmental and developmental rather than evaluative and externally required" (Lomas and Nicholls, 2005 cited in Bell and Mladenovic, 2008). By using a critical friend method we hoped to move towards Tanner's Equality Model (Tanner, 1998). However we also needed to address agencies' concerns about rigour of assessment, so guidance for the critical friend report was produced. Shortland (2010) indicates that "Checklists can constrain the observer into recording what the institution suggests is

7 'I once knew a team where all the workers called the manager "mother" '.....Some reflections on supervision within an integrated leadership and management programme

Social Work and Social Services Review article Revised May $28^{\text {th }} 2013$ 
observed, rather than what would benefit the person being observed" (Shortland, 2010, p 296), but we had to be mindful of the environment in which the training was being provided, where the rational/technical aspect of evaluation prevails (Everitt and Hardiker, 1996, cited in Tanner, 1998) and is accepted by the candidates, who themselves wanted structure as to what they were "supposed to do". According to Bell and Mladenivic (2008), peer observation can be challenging as it often involves critical reflection, exploring unsuccessful and successful experiences and providing and accepting feedback. Bell and Mladenivic (op cit) suggest peer observation should be carried out in a spirit of collegiality, while Shortland uses the concept of a "climate of respect" (Shortland, 2010 p 297). Cosh maintains that genuine learning for experienced practitioners (teachers in her case) takes place most effectively through "selfawareness, reflection and open-mindedness" (Cosh, 1999, p 25).

\section{The critical friend}

The use of the critical friend approach as a means of peer observation is a very good model for use in social work, and particularly in reflective discussion of supervision. This method of learning relates directly to Kolb's learning cycle (Kolb, 1984). A critical friend is "a trusted person who asks provocative questions, provides data to be examined through another lens, and offers critiques of a person's work as a friend. A critical friend takes the time to fully understand the context of the work presented and the outcomes that the person or group is working toward. The friend is an advocate for the success of that work" (Costa and Kallick, 1993). The roles of a critical friend can be identified as

- Offering support

- Providing challenge

- Consultancy

- Leading enquiry

- Brokering knowledge

(National College for School Leadership, no date) .

The first two functions offering support and providing challenge appeared to have the potential for fulfilling useful roles within peer observation. The concept of the critical friend contains a tension, as it involves both unconditional support and unconditional critique. In this respect it has synergy with supervision. Using a critical friend minimises the power issues involved in some other types of observation, and addresses the "insider/outsider" dynamic (Jones and Macnamara, 2004).

\section{The "shared space"}

The "shared space" describes a concept whereby professionals use a safe enclosed environment (in this case online) to discuss issues of concern to them,

8 'I once knew a team where all the workers called the manager "mother" '.....Some reflections on supervision within an integrated leadership and management programme 
in many ways similar to the idea of a community of practice (Wenger, 2006). Spinelli and Brodie (2003) emphasize the role of the "collaborative informational space" as enabling creative decision making, and suggests this can be physical, virtual or distributed (mobile phone and e mail). They found that physical space was the most effective way to support collaborative activities; virtual and distributed space was much less effective and required physical mediation when the task became complex. However, other writers see benefit in an online shared space for facilitating co-operative and collaborative learning, and promoting equality within the learning environment (Bradley and McConnell, 2002; Asensio et al 2000). Hair (2012) suggests that social work supervisors "are able to address administrative necessities AND create emotionally safe space for reflective and reflexive conversations" (my emphasis). This exercise was designed to mirror that process for supervisors themselves.

The three techniques of peer observation, critical friend and shared space combined to try and address issues of hierarchy and promote openness in learning and reflection.

\section{Findings}

\section{The discussion board exercise}

The online discussion was a structured activity. Firstly, the candidates had to look at a PowerPoint presentation "Games People Play in Supervision", (Kadushin 1968) devised by this author from Gray (2010). This was followed by reading a journal article entitled "Treat Me, Don't Beat Me" (Cousins, 2010), finally completing the reading with "An ethical practice dilemma" (Moorhead and Johnson, 2010). These activities provoked a wealth of activity on the discussion board. The overriding issue was how to manage to conflicting demands of supervision: workers can be clear about their role, yet feel unconfident, conflicted or anxious in discharging it. This is where the supervisor's practical and emotional intelligence are crucial in picking up such clues and in building the practitioner's confidence. The "Games People Play" exercise enabled two of the managers to identify such games in some of their supervisees, and also in their own managers. One candidate suggested that the "how are you?" opener of a supervision session had to be carefully managed; another reported the tactic of long lists of tasks leaving little time for case discussion. For one, the expression of high emotion, tears and stress left the manager feeling she had completely lost sight of the service user, which she was not fully aware of until describing the situation in the discussion.

9 'I once knew a team where all the workers called the manager "mother" '.....Some reflections on supervision within an integrated leadership and management programme

Social Work and Social Services Review article Revised May $28^{\text {th }} 2013$ 
Although the background and philosophy of the programme was rooted in a concern that social workers and managers were unsure of their professional identity, this was not particularly apparent in the discussions. Managers perceived that part of their role was confirming and reinforcing the professional identity of newly qualified social workers. One manager admitted that this was not something she was fully attuned to. Non social work managers found this a challenge. One candidate valued the presence of newly qualified and student social workers "listening to NQSW and trainees can bring us back to the core concepts and values of social work practice and what we started off trying to achieve". However, the need to evidence the development of newly qualified social workers was felt to be an additional task for managers.

Several participants felt managing change overwhelmed all the other supervision tasks. As well as integrating and developing newly qualified staff, managers were struggling with experienced workers resistant to new technology and to some of the concepts such as safeguarding now expected to be embedded in their practice. Organisational change created instability for some participants, with uncertainty about their own jobs, particularly in adult services. (At the end of the programme one of the candidates was made redundant).

There was considerable scepticism about multiagency working in practice, despite the fact that it has been an established facet of practice for several years. "Are we the only ones who take our safeguarding responsibilities seriously" was one comment. This reinforces the findings of Stevens (2013) who reported that "The multi-agency process of safeguarding vulnerable adults continues to pose challenges, despite agencies improving their commitment to partnership working" (Stevens, 2013 p 1). The development of highly skilled practitioners who can negotiate the landscape of different professionals as well as service users was seen as a key function of supervision: challenging difficult people, who may be other professionals, is a fundamental skill for social workers.

Finally, a discussion arose as to how to facilitate better supervision for themselves. The candidates knew what good supervision looked like, and what they were trying to provide for their staff. Some reported poor supervision experiences; others just wanted it to be better: not to be fobbed off ("organizational expectations leave little time for the items I have"); to have the emotional impact of the work acknowledged; and taking more responsibility for using their own supervision for learning and personal development, which it was felt might have a knock on effect, "having your voice heard in relation to more operational and risk issues". Asensio et al suggest that the online environment "allows practitioners to be aware of their own and others contributions and reflect on the process of expanding their interpersonal skills" (Asensio et al,

10 'I once knew a team where all the workers called the manager "mother" '.....Some reflections on supervision within an integrated leadership and management programme

Social Work and Social Services Review article Revised May $28^{\text {th }} 2013$ 
2000). The remark "I once knew a team where all the workers called the manager 'mother' " reflected some dark humour but also a level of emotional expression and concern.

These examples arose within the context of a genuine discussion which took place over the course of a day, with people leaving and returning, and commenting on what had taken place in their absence. Feedback from candidates was mixed, ranging from "I learnt far more than I would have in a face to face discussion" to "I hated the e learning day as it didn't suit my learning style".

\section{Video and critical friend exercise}

Using video provided the opportunity for candidates to reflect directly on their own practice, as well as that of their partner, thus enhancing and enriching the experience of being observed. Morrison (2007) points out that social work is a collaborative activity, not only with the service user but within and outside the organisation. Undertaking the critical friend activity should therefore indicate an open attitude to collaboration among the candidates, model good behaviour in giving and receiving feedback and enhance critical reflection in a safe environment.

The video and critical friend exercise was designed to be an integral part of the whole course. Jones and McNamara suggest that the purpose of using video in this context is to enable the participants to "unpack" aspects of their practice, first to reflect on it and then to use these reflections to implement change (Jones and Macnamara (2004). Candidates had to have completed the video by the appointed day and bring it to the university, and the pairs had to work together face to face. The crossover of adult and childrens' services experiences provided a rich exchange of material and ideas, including some specific supervision tools. Candidates appreciated similarities and identified differences, of which there were actually few in terms of what was happening in the supervision. Differences between this somewhat contrived task and normal supervision were pointed out: one candidate remarked in her reflection that that she spent 35 minutes discussing one case, which she would never normally do; however, it provoked her to think about whether this was necessary and if so how it might be possible. Participants were asked to discuss a safeguarding issue in their supervision sessions, to evidence enabling the supervisee to manage situations of conflict and risk. This provoked several lively discussions about the actual case, but also pointers as to where specific safeguarding issues could have been raised directly with the supervisee. Fook (2004) distinguishes between reflection and critical reflection where critical reflection involves "a deconstruction and reconstruction of a person's own theory of power" (Fook, 2004, p 58) and the development of transformative ways of practice. While the concepts of equality and reciprocity we had hoped to engender were apparent in the exercise, most

11 'I once knew a team where all the workers called the manager "mother" '.....Some reflections on supervision within an integrated leadership and management programme 
candidates were affirming towards their colleagues and were able to give constructive feedback, though not with the depth indicated by Fook above. As in Jones and Macnamara's work, the exercise "provided insights into individual ideals, beliefs and assumptions" (Jones and Macnamara. 2004, p9). The exercise made a strong impact on the candidates, with remarks such as "I was daunted by the task but found it extremely helpful"; "It was easier to receive critical feedback than to give it". One candidate remarked on the safe space provided for reflection. Changes in personal practice in supervision were indicated, with replies to the feedback question How will you apply what you've learned to your work including comments such as "I've already changed our service's approach to supervision"; "be more caring and less task centred" ; "use critical friend technique".

\section{Discussion}

This article arose from the discussion board and the interesting material which emerged: candidates were tussling with live issues in their practice in an open way, given the opportunity created by the "shared space". Additionally, the critical friend video exercise provided a forum for face to face discussion which some candidates preferred.

Phillipson (2009) remarks on the widespread acceptance of supervision in its current form, and the lack of challenge to and criticism of its formulation. One to one, face to face supervision is regarded as the norm and indeed the ideal; though some of these managers were implementing alternatives such as group supervision, and were receiving this themselves, this was seen as an alternative to "proper" supervision, which if fulfilling all it's functions does "tick all the boxes", sometimes literally. There is no doubt that the challenges of social work practice in both adults and children's services, in a very uncertain professional world, mean that practitioners need an anchor. The criticism in various inquiries as to how supervision has been carried out, and the present focus on it as part of the social work reform agenda, puts managers in the spotlight. The managers on this course demonstrated a robust and pragmatic approach. They were conscious of the need to provide a safe space for emotional containment within the supervision session, as mirrored by the discussion board activity; they were very aware of their responsibilities both to their staff and to the organisation, and saw themselves as having a pivotal role, which, while daunting, also invoked a sense of pride. They were aware of the leadership skills they needed as being "close, sociable, open with a sense of humour and with high performance standards for themselves and their team" (a quote from the discussion board), but also having a secure personal life, good peer relationship, a constructive relationship with their own supervisor and job security. Phillipson (2009) suggests that the lack of critical analysis of supervision may be because it meets

12 'I once knew a team where all the workers called the manager "mother" '.....Some reflections on supervision within an integrated leadership and management programme 
the needs of a task oriented organisation, within which our managers have to fit and to function. It is also familiar - all social work managers will have progressed professionally through a system where supervision is standard and expected (even if not always provided). Recent suggestions (Munro, 2011) that supervision functions should be split between managerial oversight and professional supervision did not feature in the discussions of these managers. The surveillance function of supervision outlined by Beddoe (2010) was acknowledged but taken for granted.

Safeguarding is not as securely embedded in adults as in children's services (Manthorpe and Martineau, 2010). For adult services managers, who were typically managing large disparate multi professional teams with unqualified staff, to focus on safeguarding issues with colleagues from children's services provided an open and safe forum for exploration of how to manage the issues. As has already been mentioned, participants were sceptical about the value of multi agency working; however, the findings from this exercise suggest that there is considerable benefit to be derived from managers working together on the specific issue of safeguarding, while the benefit of inter -professional learning more generally still needs empirical evidence to convince practitioners (Stevens 2013) (and this was also the view of our original development group). The contributions of adult services and children's services participants were indistinguishable (except where they were making a specific point about their service). Concerns were the same across both sectors: how to manage the demands of the organisation, how to support staff, how to provide a high quality service for users. These are key issues for all social work managers. Providing a safe space for managers allowed exploration of many of the issues in contemporary supervisory practice. The work undertaken by these managers demonstrated the value of adult and children's managers working together. Adult managers learnt from the longer experience of children's services in safeguarding; children's services appreciated the management skills of colleagues managing very wide and disparate teams.

Hawkins and Shohet (2012) suggests that supervision should begin with "self supervision", and that for both the supervisor and supervisee, supervision forms the means for ongoing self- development, self- awareness and commitment to professional development. The combined methods of the shared space discussion board and the critical friend exercise provided an opportunity for reflection which most of the participants intended to carry forward into their future practice.

Word count 4830

13 'I once knew a team where all the workers called the manager "mother" '.....Some reflections on supervision within an integrated leadership and management programme

Social Work and Social Services Review article Revised May $28^{\text {th }} 2013$ 
Asensio, M., Hodgson V. and Trehan, K. (2000) "Is there a difference? Contrasting experiences of face to face and on line learning" http://www.networkedlearningconference.org.uk/past/nlc2000/Proceedings/Ase nsio 12-19.pdf) accessed $1^{\text {st }}$ November 2012

Beddoe, L. (2010) "Surveillance or reflection: professional supervision in 'the risk society' ", British Journal of Social Work, vol 40 pp 1279 - 1296

Bell, A. and Mladenovic, R. (2008) "The benefits of peer observation of teaching for tutor development" Higher Education vol 55 pp735 -752

Biggs, J. (2003) "Teaching for quality learning at university: what the student does", Maidenhead: Society for Research into Higher Education and Open University Press

Bradley, S. and McConnell, D. (2002)" Virtual learning groups in learning environments: collaboration, co-operation or self centred individualism", Proceedings of the $6^{\text {th }}$ International Conference on Networked Learning, Lancaster University

http://www.academia.edu/670800/Virtual Groups in Learning Environments C ollaboration Cooperation or Self Centred Individualism accessed 1st November 2012

Brandon, M., Dodsworth, J. and Rumball, D. (2005) "Serious case reviews: learning to use expertise", Child Abuse Review vol 14, no 3 pp 160 -1

Brandon, M. Bailey, S. and Belderson, P. (2010) "Building on the learning from serious case reviews: a two-year analysis of child protection database notifications 2007-2009", Department for Education Research Brief RB 040 https://www.education.gov.uk/publications/standard/publicationdetail/page1/DF E-RR040 accessed $14^{\text {th }}$ June 2012

Community Care "Fiona Pilkington SCR questions adults safeguarding policy", $30^{\text {th }}$ September 2009

http://www.communitycare.co.uk/Articles/30/09/2009/112729/fiona-pilkingtonscr-questions-safeguarding-adults-policy.htm accessed 1st November 2012

Cosh, J. (1999), "Peer observation: a reflective model" ELT Journal vol 53, pp 22

Costa, A. and Kallick, B. (1993) "Through the Lens of a Critical Friend".

Educational Leadership 51(2) 49-51

14 'I once knew a team where all the workers called the manager "mother" '.....Some reflections on supervision within an integrated leadership and management programme

Social Work and Social Services Review article Revised May $28^{\text {th }} 2013$ 
Cousins, C., 2010, "Treat me don't beat me - exploring supervisory games and their effect on poor performance management", Practice - Social Work in Action vol 22 no 5)

Department for Education, (2003) "Every Child Matters"

http://www.education.gov.uk/consultations/downloadableDocs/EveryChildMatter s.pdf accessed $14^{\text {th }}$ June 2012

Department for Education, (2012) Standards for Employers and Supervision Framework http://www.education.gov.uk/swrb/a0074263/standards-foremployers-and-supervision-framework) accessed $14^{\text {th }}$ June 2012

Department of Health (2000) "No Secrets - guidance on developing and implementing multi agency policies and procedures to protect vulnerable adults from abuse"

http://www.dh.gov.uk/en/Publicationsandstatistics/Publications/PublicationsPolic yAndGuidance/DH 4008486 accessed $27^{\text {th }}$ June 2012

Department of Health (2003) "The Victoria Climbie Inquiry: Report of an inquiry by Lord Laming", The Stationery Office

http://www.dh.gov.uk/en/Publicationsandstatistics/Publications/PublicationsPolic yAndGuidance/DH 4008654 accessed 15th June 2012

Department of Health (2007) "Putting People First: a shared vision and commitment to the transformation of adult social care",

http://www.dh.gov.uk/en/Publicationsandstatistics/Publications/PublicationsPolic yAndGuidance/DH 081118 accessed $14^{\text {th }}$ June 2012

Dustin, D. (2007) "The McDonaldization of social work" Aldershot: Ashgate

Everitt, A., and Hardiker, P. (1996), "Evaluating for good practice", Basingstoke: Macmillan

Ferguson, H. (2010) "Walks, Home visits and atmospheres: risk and the everyday practices and mobilities of social work and child protection", British Journal of Social Work vol 40 pp $1100-1117$.

Fish, S., Munro, E. and Bairstow, S., (2008) "Learning together to safeguard children: developing a multi-agency systems approach for case reviews", SCIE Report 19 http://www.scie.org.uk/publications/guides/guide24/files/guide24.pdf accessed $14^{\text {th }}$ June 2012

15 'I once knew a team where all the workers called the manager "mother" '.....Some reflections on supervision within an integrated leadership and management programme

Social Work and Social Services Review article Revised May $28^{\text {th }} 2013$ 
Flynn, M. (2007) "The Murder of Steven Hoskin: Serious Case Review Executive Summary", Cornwall Adult Protection Committee, Cornwall County Council http://www.cornwall.gov.uk/Default.aspx?page $=5609$ accessed $15^{\text {th }}$ June 201

Fook, J. (2004) "Critical reflection and organizational learning and change: a case study", chapter 4 in Gould, N. and Baldwin, M, "Social work, critical reflection and the learning organisation", Aldershot: Ashgate

Gray, I. (2010) "The role and importance of supervision", Chapter 4 in Gray, I., Field, R. and Brown, K. "Effective Leadership, Management and Supervision in Health and Social Care", Exeter: Learning Matters

Gray, M and Schubert, L (2012) "Sustainable social work: modelling knowledge production, transfer and evidence -based practice", International Journal of Social Welfare vol 21 pp203 -214

Hair, H. (2012) "The purpose and duration of supervision, and the training and discipline of supervisors: what social workers say they need to provide effective services" British Journal of Social Work advanced access published May $30^{\text {th }}$ 2012

http://bjsw.oxfordjournals.org/content/early/2012/05/29/bjsw.bcs071.full.pdf+h tml?sid=09e572d3-b27b-4f69-9d24-39dc31ac86a5 accessed $15^{\text {th }}$ June 2012

Harris, J. (2003) "The Social Work Business", London: Routledge

Hawkins, P. and Shohet, R. (2012) "Supervision in the helping professions", Maidenhead, Open University Press

Hawkins, P and Smith, N. (2006) "Coaching, mentoring and organizational Consultancy: supervision and development" Maidenhead: Open University Press

Jones, M. (2004) "Supervision, learning and transformative practices", chapter 1 in Gould, N. and Baldwin, M. "Social Work, critical reflection and the learning organisation", Aldershot: Ashgate

Jones, L. and Macnamara, O. (2004) "The possibilities and constraints of multimedia as a basis for critical reflection", Cambridge Journal of Education vol 34 , no. 3

Kadushin, A (1968) "Games people play in supervision", Social Work, vol.13, 3, pp23-32.

Kadushin, A (1992), "Supervision in Social Work", $3^{\text {rd }}$ edn. New York: Columbia University Press

16 'I once knew a team where all the workers called the manager "mother" '.....Some reflections on supervision within an integrated leadership and management programme

Social Work and Social Services Review article Revised May $28^{\text {th }} 2013$ 
Kolb, D. A. (1984) "Experiential Learning", Englewood Cliffs, NJ.: Prentice Hall

Laming, (2009) "The Protection of Children in England: a Progress Report", Department for Education

https://www.education.gov.uk/publications/eOrderingDownload/HC-330.pdf accessed $15^{\text {th }}$ June 2012

Lawler, J. and Bilson, A. (2010) "Social work management and leadership: Managing complexity with creativity", London: Routledge

Lomas, L and Nicholls, G. (2005) "Enhancing teaching quality through peer review of teaching", Quality in Higher Education" vol 11, 2 pp137 -149

Manthorpe, J and Martineau, S. (2010) "Serious Case Reviews in adult safeguarding in England: an analysis of a sample of reports" British Journal of Social Work, vol 41 pp $224-241$

Morrison, T. (2007) "Emotional intelligence, emotion and social work: context, characteristics, complications and contribution", British Journal of Social Work, vol 37, pp245 -263

Morrison and Wonnacott, 2010 http://www.in-trac.co.uk/reclaiming-reflectivesupervision.php)

Moorhead, B. and Johnson, S. (2010) "An Ethical Practice Dilemma involving a New Social Work Graduate", Practice - Social Work in Action, vol 22 no 1)

Munro, E. (2010) "The Munro review of child protection: interim report The Child's Journey" Department for Education

https://www.education.gov.uk/publications/standard/publicationDetail/Page1/DF E-00010-2011 accessed 15th June 2012

Munro, E. (2011) "The Munro review of child protection: final report A Child Centred System", Department for Education

http://www.education.gov.uk/munroreview/downloads/8875 DfE Munro Report TAGGED.pdf accessed 1st November 2012

National College for School Leadership (no date) "What does a critical friend do?" http://networkedlearning.ncsl.org.uk/collections/network-leadership-inaction/nlg-what-does-a-critical-friend-do.pdf ) accessed 27th November 2012.

Parsloe, P., 1981 "Social Services Area Teams", London: George Allen and Unwin, in Harris, 2003.

17 'I once knew a team where all the workers called the manager "mother" '.....Some reflections on supervision within an integrated leadership and management programme

Social Work and Social Services Review article Revised May $28^{\text {th }} 2013$ 
Parton, N. (2011) "Child protection and safeguarding in England - changing and competing conceptions of risk and their implications for social work", British Journal of Social Work vol 41, pp 854 - 875

Phillipson, J. (2009) "Supervision and being supervised", chapter 15 in Adams, R., Dominelli, L. and Payne, M. "Practising social work in a complex world", $2^{\text {nd }}$ edition, Basingstoke: Palgrave Macmillan

Ritzer, G. (1996) "The McDonaldization of society", Thousand Oaks: Sage

Satyamurti, C. (1981) "Occupational survival", Oxford: Blackwell, in Harris, 2003 Skills for Care (2010) "Invitation to tender and specification: Training and support for front line social work managers: Employer-led demonstration sites", Leeds: Skills for Care

Shortland, S. (2010) "Feedback within peer observation: continuing professional development and unexpected consequences" Innovation in Education and Teaching International vol 47 no 3, pp295-304

Social Work Task Force (2009) "Building a Safe and Confident Future" https://www.education.gov.uk/publications/standard/publicationdetail/page1/DC SF-01114-2009 accessed 15th June 2012

Spinelli, D. and Brodie, J. (2003) "Towards an understanding of Common Information Spaces in Distributed and Mobile Work", Brunel University http://www.brunel.ac.uk/ cssrmjp/dismob/hciiSpinelli.pdf accessed 15th June $\underline{2012}$

Stevens, E. (2013) "Safeguarding vulnerable adults: exploring the challenges to best practice across multi-agency settings" Journal of Adult Protection Vol. 15 no 2, p $85-95$

Tanner, K. (1998) "Towards an equality model - observation through a power lens", chapter 2 in Le Riche, P. and Tanner, K. "Observation and its application to social work - rather like breathing", London: Jessica Kingsley

Wenger, E. (2006) "Communities of practice - a brief introduction", http://www.ewenger.com/theory/ Accessed 14th June 2012

18 'I once knew a team where all the workers called the manager "mother" '.....Some reflections on supervision within an integrated leadership and management programme

Social Work and Social Services Review article Revised May $28^{\text {th }} 2013$ 
19 'I once knew a team where all the workers called the manager "mother" '.....Some reflections on supervision within an integrated leadership and management programme

Social Work and Social Services Review article Revised May $28^{\text {th }} 2013$ 